\title{
BACTERIAL CONTAMINATION OF STETHOSCOPES IN UNIVERSITY HOSPITALS - MULTICENTER STUDY
}

\author{
Stefan Bošković ${ }^{1}$, Karim Sharawy², Sara Rodriguez Alonso ${ }^{3}$, Branislava Savić ${ }^{4}$ \\ ${ }^{1}$ Faculty of Medicine, University of Belgrade, Serbia \\ ${ }^{2}$ Faculty of Medicine, Benha University, Egypt \\ ${ }^{3}$ Hospital Clinic, University of Barcelona, Spain \\ ${ }^{4}$ Mentor: Institute of Microbiology and Immunology, Faculty of Medicine, University of Belgrade, Serbia \\ Contact e-mail: stefan92boskovic@yahoo.com
}

\section{Sažetak}

Uvod: Membrana stetoskopa predstavlja pogodnu sredinu za preživljavanje bakterija i kontaminira se prilikom pregleda pacijenata. Ukoliko se ne dezinfikuje, može predstavljati izvor infekcije i doprineti razvoju bolničkih infekcija.

Cilj: Cilj ovog rada je ustanoviti učestalost kontaminacije membrana stetoskopa, identifikovati prisutne mikroorganizme, ispitati njihovu osetljivost na antimikrobne lekove i utvrdi da li postoji razlika u kontaminaciji membrana stetoskopa u zavisnosti od redovnosti čišćenja u univerzitetskim klinikama u Beogradu, Benhi i Barseloni.

Materijal i metode: Brisevi membrana stetoskopa su uzeti od 147 lekara zaposlenih u jednoj od tri univerzitetske klinike u Beogradu, Benhi ili Barseloni. Lekari su anketirani o navikama održavanja stetoskopa. Materijal je zasejan i inkubiran u dekstrozni bujon i na krvni agar. Nakon porasta kolonija identifikovane su na osnovu kulturelnih, mikroskopskih i biohemijskih osobina i upotrebom MALDI-TOF. Osetljivost na antimikrobne lekove ispitana je disk difuzionim metodom.

Rezultati: Samo 12 lekara svoje stetoskope dezinfikuje nakon pregleda svakog pacijenta. 122 uzorka su bila kontaminirana, 25 sterilna (1 iz Beograda i 24 iz Benhe). Ne postoji statistički značajna razlika u stepenu kontaminacije stetoskopa i redovnosti čišćenja ( $\mathrm{p}$ > $0,05)$. Stetoskopi u Benhi su statistički značajno manje kontaminirani $(\mathrm{p}<0,05)$. Izolovane bakterije pripadaju rodovima Staphylococcus (125 sojeva), Streptococcus (7 sojeva), Bacillus (5 sojeva), Corynebacterium (13 sojeva), Acinetobacter (2 soja), Proteus (2 soja), Enterococcus (1 soj) i Pseudomonas (1 soj). Rezistencija na meticilin koagulaza negativnih stafilokoka iznosi 37,1\% u Beogradu, a u Benhi 95,2\%. Izolovana su 4 soja Staphylococcus aureus, 3 su bila rezistentna na meticilin.

Zaključak: Dezinfekciju membrane stetoskopa bi trebalo sprovoditi posle pregleda svakog pacijenta i neophodna je edukacija lekara o njenom značaju.

Ključne reči: Stetoskop, koagulaza negativni stafilokok, rezistencija na meticilin

\section{Abstract}

Introduction: Stethoscope membranes provide a suitable environment for bacterial survival and they get contaminated during examination of patients. If they are not disinfected, they can become a source of nosocomial infections.

Aim: Determine the level of contamination of stethoscope membranes, identify the present microorganisms, test their antimicrobial susceptibility and determine whether there is a difference in contamining based on the frequency of disinfection in university clinics in Belgrade, Benha and Barcelona.

Material and methods: Swabs were taken from stethoscope membranes of 147 physicians who are employed in one of three university hospitals in Belgrade, Benha and Barcelona. The material was cultivated and incubated in dextrose broth and on blood agar plates. Identification was performed by cultural, microscopic and biochemical characteristics and the use of MALDI-TOF. Disc diffusion method was used for antimicrobial susceptibility testing.

Results: Only 12 doctors disinfect their stethoscopes regularly. Out of 147 samples, 122 were contaminated, and 25 sterile ( 1 from Belgrade, 24 from Benha). There was no statistically significant difference in degree of contamination and cleaning habits $(\mathrm{p}>0.05)$. Stethoscopes in Benha were significantly less contaminated $(\mathrm{p}<0.05)$. Isolated bacteria belong to genera Staphylococcus (125 strains), Streptococcus (7 strains), Bacillus (5 strains), Corynebacterium (13 strains), Acinetobacter (2 strains), Proteus (2 strains), Enterococcus (1 strain) and Pseudomonas (1 strain). Methicillin resistance of staphylococci was $37.1 \%$ in Belgrade and $95.2 \%$ in Benha. Four strains of Staphylococcus aureus were isolated and three were methicillin-resistant.

Conclusion: Disinfection of stethoscope membranes should be performed after examining each patient and it is necessary to conduct further education of physicians on this matter.

Key words: Stethoscope, coagulase negative staphylococci, methicillin resistance 


\section{Introduction}

Although we live in the so-called modern society and have a vast number of antibiotics at our disposal, deadly healthcare-associated infections (HAI) are still an enormous problem for modern medicine. During 2013 in the EU about 4.2 million patients acquired HAI, most common HAI are blood infections, urinary tract infections, infections of surgical site and pneumonia. Most usual pathogens causing nosocomial infections are Staphylococcus aureus, coagulase negative staphylococci, Acinetobacter spp., Enterococcus spp. and Klebsiella spp. [1]

The most common way of transferring infections between patients is through direct contact with hospital workers, especially hands of hospital personnel. Stethoscope membranes are surfaces where bacteria can survive on and the level of contamination can be compared to the contamination of thenar eminence of the hospital worker's hands $[2,3]$. After examining a few patients in a row without disinfecting the membrane, microorganisms can be passed from one patient to another, so stethoscope membranes can become a source of nosocomial infections. According to the Guideline for Disinfection and Sterilization in Healthcare Facilities [4], stethoscopes belong to low risk materials. Therefore physicians very often neglect disinfection of stethoscopes and consider it of little importance.

The aim of this study is to determine the level of contamination of stethoscope membranes, identify the present microorganisms, test their antimicrobial susceptibility and determine whether there is a difference in contamination depending on the frequency of disinfection in university clinics in Belgrade (Serbia), Benha, (Egypt) and Barcelona, (Spain).

\section{Material and methods}

The study was carried out from January 27th 2015 till March 3rd 2015. The following institutions were included in the study: Clinical Center of Serbia (Clinic for Pulmonology, Clinic for Cardiology, Clinic for Emergency Internal Medicine), Clinic for Internal medicine Hospital Clinic of Barcelona, Clinic for Pediatrics Hospital Clinic of Barcelona, Clinic for Internal Medicine of University Hospital in Benha and Clinic for Pediatrics of University Hospital in Benha. In total 147 physicians (39 specialists in pediatrics, 106 specialists in internal medicine, and two anesthesiologists) who use stethoscopes in their everyday practice were included in the survey. Sampling of stethoscopes and involvement of the physicians were approved by the Ethics Committees of the respec- tive hospitals. Since the surface of the stethoscope is dry, swabs moistened in sterile saline were used. The entire surfaces of stethoscope membranes were swabbed including the edges following aseptic techniques. In addition to the sampling, questionnaires regarding handling of the stethoscopes and cleaning practices were given to physicians participating in the study.

Microbiological analyses were carried out at the Institute of Microbiology and Immunology, School of Medicine, University of Belgrade, Unit of Microorganisms at the Clinical Pathology Department, Faculty of Medicine University of Benha and Institute of Pathology, Pharmacology and Microbiology, Hospital Clinic University of Barcelona.

Transport of the material to microbiological laboratories lasted less than two hours. The material was inoculated onto blood agar plates and into dextrose broth and incubated for up to 48 hours at $37^{\circ} \mathrm{C}$. After the growth of colonies, bacteria were identified based on their cultural, microscopic and biochemical characteristics [5]. Isolates from Barcelona were identified by using Matrix-Assisted Laser Desorption/Ionization - Time Of Flight (MALDI-TOF) [6].

Depending on the number of isolated species the level of contamination was arbitrarily classified as:

1. up to two isolated strains - low level of contamination,

2. three isolated strains - moderate level of contamination,

3. more than three isolated strains - high level of contamination [7].

Antimicrobial susceptibility testing was performed for the isolates of possibly clinically relevant bacteria, i.e. for the isolates of Staphylococcus spp., Acinetobacter spp. and Proteus spp. in Belgrade, for the isolates of S. aureus in Barcelona and for the isolates Staphylococcus spp. in Benha. The testing was performed by the disc diffusion method in accordance with the recommendations from The European Committee on Antimicrobial Susceptibility Testing (EUCAST) [8].

Criterion for multiresistance was resistance to three or more groups of antibiotics with different mechanism of action [9].

Statistical significance value was calculated by the use of Fisher's exact test and Chi-square test and was set at the value of 0.05 . Correlation was calculated by determining the Spearman's rank correlation coefficient.

\section{Results:}

Out of 147 physicians who took part in the study, only one (1.66 \%) in Belgrade, five in Barcelona (11.9 \%) and six in Benha (13.33\%) disinfect their stethoscopes 
after examining each patient. Physicians employed at the Clinic for Pulmonology, Clinical Center of Serbia always disinfect their stethoscopes after examining a patient with tuberculosis. About $60 \%$ of physicians never disin- fect their stethoscopes and some 20-40\% disinfect their stethoscopes once a day, usually before or after rounds. The frequency of disinfection is shown in Graph $\mathbf{1}$.

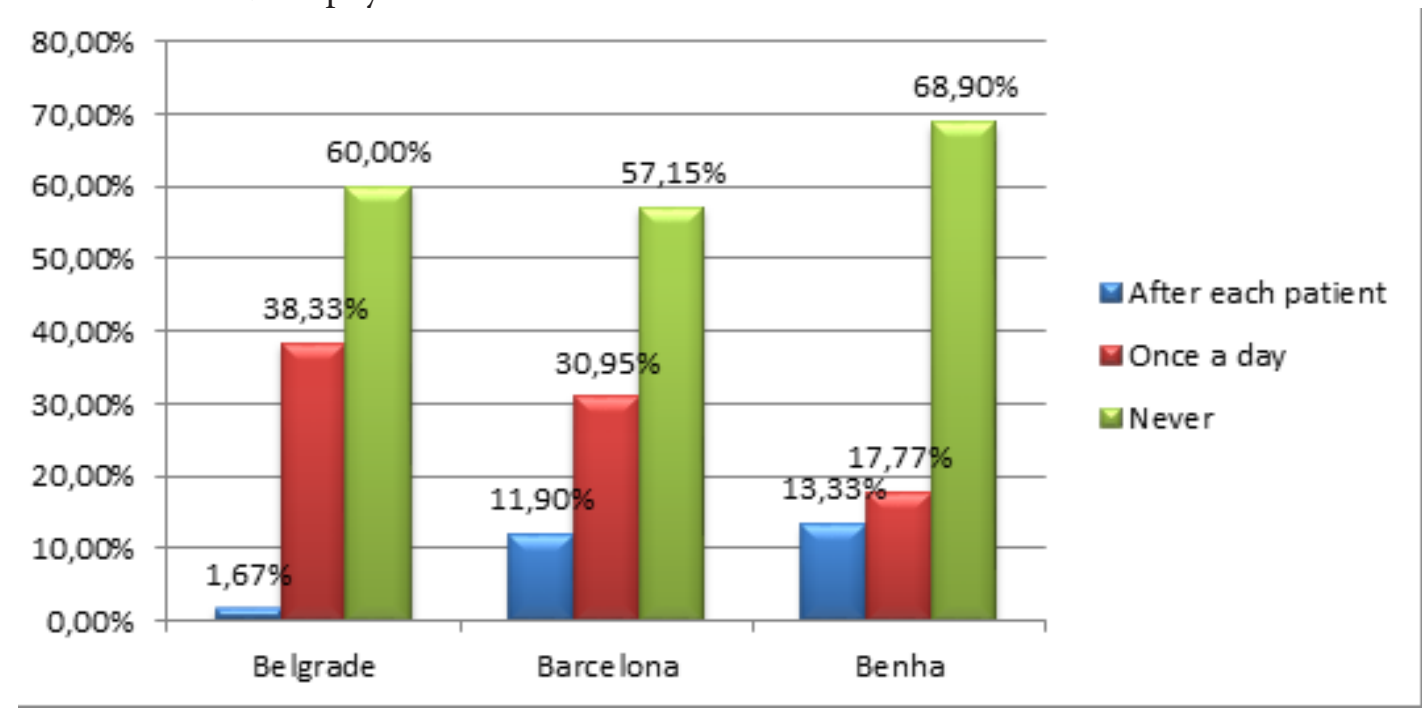

Graph 1. Frequency of disinfection of stethoscopes

As the main reasons for neglecting to disinfect their stethoscopes regularly, physicians emphasize forgetfulness ( 92 physicians), lack of time ( 81 physicians) and lastly lack of disinfectant (seven physicians). They also pointed out that in due course disinfectants can damage membranes. In Belgrade the most commonly used disinfectant is $70 \%$ ethanol, in Barcelona alcoholic gel and in Benha 70\% isopropyl alcohol.
Out of 147 samples tested, 122 yielded positive results, i.e. growth of bacteria. There were 24 sterile samples in Benha and one in Belgrade. None of the sterile samples belonged to the physicians who clean their stethoscopes after examining each patient. In Benha there are statistically fewer contaminated stethoscopes than in Belgrade and Barcelona ( $<$ 0.05) (Graph 2).

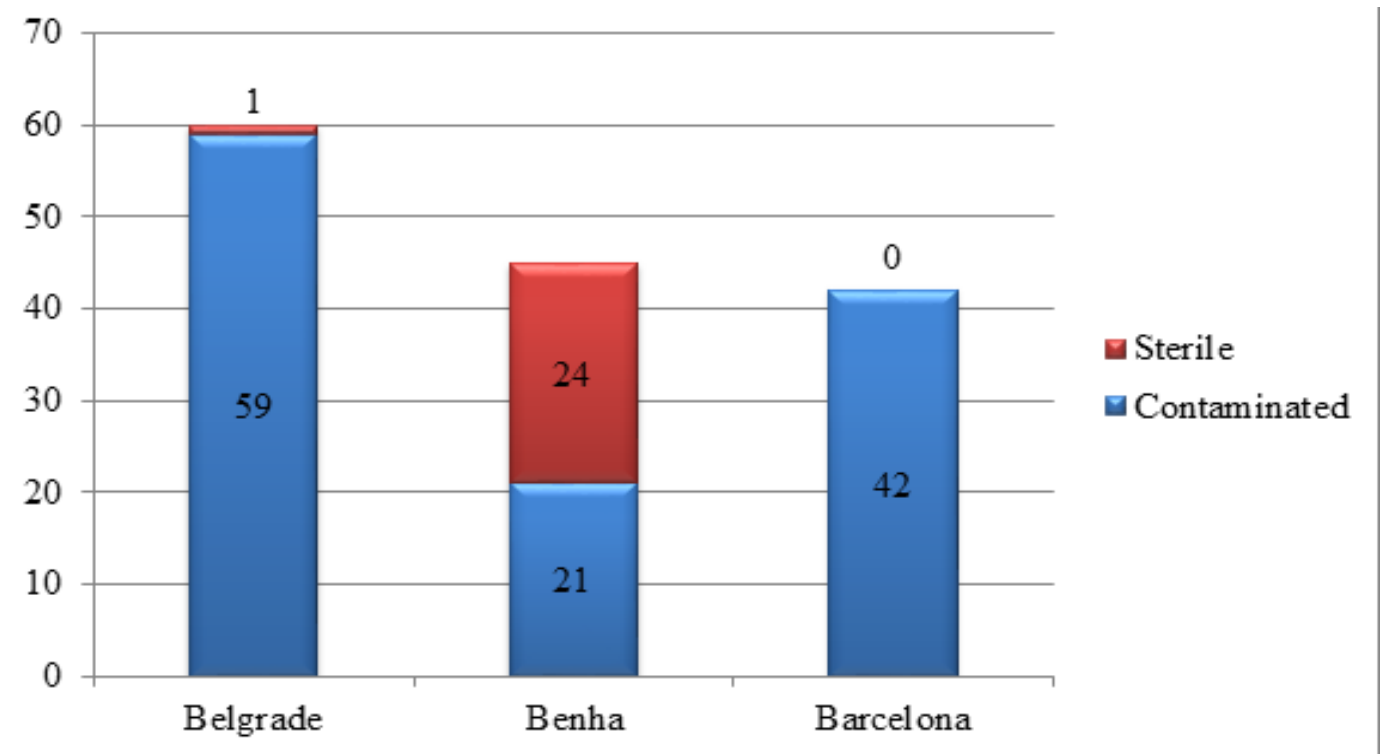

Graph 2. Number of sterile and contaminated stethoscopes samples per city.

There was no statistically significant differences in membranes contamination between the physicians who disinfect their stethoscopes after examining each patient and those who do that rarely $(\mathrm{p}>0.05)$.

Low level of contamination was found at 57 steth- oscopes in Belgrade, 40 in Barcelona and 21 in Benha; moderate level was found at two in Belgrade and two in Barcelona; high level of contamination was not found. There was no correlation between the frequency of cleaning and the level of contamination $(\rho=0)$. 
Isolated bacteria and number of isolates per city is shown in Table 1. The most isolates belong to genus Staphylococcus genus, which is predominant in normal microflora of the skin. In total, four strains of S. aureus were isolated. All strains belonging to Streptococcus genus produced $\alpha$-hemolysis on blood agar plates, while all Corynebacterium isolates were identified as diphtheroids. Only three isolates are not considered members of normal skin microflora, namely two Proteus spp. and one Enterococcus spp. isolates.

Table 1. Presence of different bacterial species on stethoscopes in three hospitals

\begin{tabular}{|llll|} 
Genera & $\begin{array}{l}\text { Belgrade } \\
\text { № }\end{array}$ & $\begin{array}{l}\text { Barcelona } \\
\text { № }\end{array}$ & $\begin{array}{l}\text { Benha } \\
\text { № }\end{array}$ \\
\hline Staphylococcus & 62 & 42 (1 S. aureus) & 21 (3 S. aureus $)$ \\
\hline Streptococcus & - & 7 & - \\
\hline Bacillus & 5 & - & - \\
\hline Corynebacterium & 13 & - & - \\
\hline Acinetobacter & 2 & - & - \\
\hline Proteus & 2 & - & - \\
\hline Enterococcus & 1 & - & - \\
\hline Pseudomonas & - & 1 & - \\
\hline
\end{tabular}

Number of staphylococcal strains isolated at different clinics of the Clinical Center of Serbia, Belgrade, as well as their resistance patterns are shown in Table 2. It should be noted that the highest proportions of multiresistant strains $(61,9 \%)$ and strains resistant to methicillin $(57,1 \%)$ were noted among the staphylococcal strains isolated from stethoscopes used at the Department of Emergency Internal Medicine. The lowest proportions of multiresistant $(23,8 \%)$ and methicillin-resistant $(14,3 \%)$ staphylococci were noted among strains from stethoscopes used at the Clinic for Cardiology which is statistically significantly less than in all other clinics $(\mathrm{p}<0,05$.). There is no statistically significant difference in resistance to methicillin among isolated strains depending on disinfection of stethoscopes $(\mathrm{p}>0.05)$.

Table 2. Number and resistance patterns of staphylococci isolated from stethoscopes in different clinics in Clinical Center of Serbia in Belgrade

\begin{tabular}{|llll|} 
Department & $\begin{array}{l}\text { № of } \\
\text { staphylococci }\end{array}$ & $\begin{array}{l}\text { Resistance to } \\
\text { methicilin №(\%) }\end{array}$ & $\begin{array}{l}\text { Multiresistanance } \\
\text { №(\%) }\end{array}$ \\
\hline Cardiology & 21 & $3(14,3 \%)$ & $5(23,8 \%)$ \\
\hline Pulmology & 20 & $8(40 \%)$ & $11(55 \%)$ \\
\hline $\begin{array}{l}\text { Emergency } \\
\text { internal medicne }\end{array}$ & 21 & $12(57,1 \%)$ & $13(61,9 \%)$ \\
\hline Total & 62 & $23(37,1 \%)$ & $29(46,8 \%)$ \\
\hline
\end{tabular}

In Belgrade there were 62 isolated strains of genus Staphylococcus and all of them were coagulase negative.

The remaining strains isolated from stethoscopes in Belgrade were one multidrug resistant Acinetobacter spp. displaying susceptibility to colistin only and two Proteus mirabilis isolates which did not exhibit multidrug resistant profiles.

As far as staphylococci isolated from stethoscopes in Benha are concerned (Table 3.) their number and methicillin-resistance patterns do not differ significantly between the two departments included in the study. The noteworthy result is an extremely high proportion $(95,23 \%)$ of isolates displaying resistance to methicillin. Although there were fewer stethoscopes contaminated in Benha than in Belgrade, the resistance to methicillin is much higher.

Table 3. Number and resistance patterns of staphylococci isolated from stethoscopes in different departments in hospital in Behna

\begin{tabular}{|lll|} 
Department & $\begin{array}{l}\text { № of } \\
\text { staphylococci }\end{array}$ & Resistance to methicilin №(\%) \\
\hline $\begin{array}{l}\text { Internal } \\
\text { medicine }\end{array}$ & 10 & $9(90 \%)$ \\
\hline Pediatrics & 11 & $11(100 \%)$ \\
\hline Total & 21 & $20(95,23 \%)$ \\
\hline
\end{tabular}

In Benha, 21 strains of genus Staphylococcus were isolated, 18 strains were coagulase negative and three were $S$. aureus. There is statistically significant difference in methicillin resistance between strains isolated in Belgrade and Benha $(\mathrm{p}<0.05)$.

In Barcelona 42 Staphylococcus spp. (one was coagulase positive), seven Streptococcus spp. strains and one Pseudomonas spp. were isolated. Isolated S. aureus was found at the Clinic of Internal medicine and it was susceptible to all tested antibiotics.

\section{Discussion}

This research was a multicenter study which tested the contamination of stethoscope membranes, ways of maintaining stethoscope cleanliness and physician habits. The research showed that great majority $(91.8 \%)$ physicians who took part don't disinfect their stethoscope frequently enough. The data don't differ from the information found in previous researches which show that 97\%-100\% physicians don't disinfect their stethoscopes regularly $[10,11]$.

The percentage of contaminated stethoscopes (in Belgrade $98.4 \%$, in Barcelona 100\%) is similar to the information found in other studies of similar design (79\%$100 \%)[10,11,12,13]$. The data from Benha (46.67\%) show that their stethoscopes are less drastically contami- 
nated and the data are not in compliance with other similar studies. The only spotted difference between cities is that physicians use a different disinfectant which should not have any effect on the difference between cities [14].

Physicians disinfect their stethoscopes in accordance with recommendation of Centers for Disease Control and Prevention - CDC [4]. Disinfectants are not always available and physicians suggested that they should be placed in patients' rooms and many other places in hospitals. Some physicians said that regular use of disinfectants may damage their stethoscopes, but this has not been proven. The Manuals of manufactures Littmann $^{\odot}$ and Spirit ${ }^{\circledR}$ point out that stethoscopes should be cleaned regularly either with disinfectants or soap and water (5 year guarantee).

With the exception of $P$. mirabilis and species belonging to genus Enterococcus, isolated strains are members of skin microflora. Dominantly isolated coagulase negative staphylococci, as the most numerous members of skin microflora, are in accordance with the use of stethoscopes. Species and their number found in this research does not differ from the results in other studies of similar type (Staphylococcus, Streptococcus and Corynebacterium) $[7,10,11,13]$. Our research has confirmed that survival of bacteria is possible on stethoscope membranes. Species belonging to Enterococcus and P. mirabilis indicate fecal contamination.

Resistance of staphylococcal strains to methicillin in Clinics of Clinical center of Serbia is $37.1 \%$ and is higher than data shown in other similar researches where resistance to methicillin in hospital environment is round $30 \%[15,16]$. Very high resistance to methicillin as well as the presence of multiresistant species from genus Acinetobacter and P. mirabilis is a characteristic of intensive care units. This shows that wards with difficult, life threatened patients who are not capable to maintain personal hygiene and lack of disinfectant near patients represent a high risk environment for development of methicillin and multiresistant bacetria.

Resistance to methicillin of strains isolated in Benha (95.23\%) is alarming and it is not in correspondence with the data available from previous studies, also it is important to emphasize that all three isolated $S$. aureus were methicillin resistant (MRSA).

In conclusion microflora isolated from stethoscope membranes presents a big resistance gene pool to methicillin and other antibiotics, also hospital sanitary conditions should be improved as well as better care of critically ill patients. All of this can lead to development of multiresistant bacteria which cause nosocomial infections and are very difficult to treat difficult HAI. It is necessary to educate physicians on the importance of regular disinfection of membranes. In that way transfer of microflora between patients, the resistance gene pool and the incidence of nosocomial infections HAI caused by multiresistant strains could be reduced.

\section{Acknowledgements}

I would like to express my immense gratitude to Dr Francesc Marco, Dr Miriam Alvarez, Dr Josep Maria Grau Junyent, Dr Soheir Abd Alrahman Abd Alsamea, Dr Afaf Fathi Khamis and student Yasser Elhabashy for all their help and work without which this research would not be possible.

\section{References:}

1. European Centre for Disease Prevention and Control. Annual epidemiological report Antimicrobial resistance and healthcare-associated infections. Stockholm: ECDC; 2014. Available online from: http://ecdc.europa.eu/en/ publications/Publications/antimicrobial-resistance-annual-epidemiological-report.pdf

2. Neely AN, Maley MP. Survival of enterococci and staphylococci on hospital fabrics and plastic. J Clin.Microbiol. 2000;38:724-726.

3. Longtin Y, Schneider A, Tschopp C, Renzi G, Gayet-Ageron A, Schrenzel J et al. Contamination of stethoscopes and physicians' hands after a physical examination. Mayo Clin Proc. 2014;89:291-9.

4. Centers for Disease Control and Prevention. Guideline for Disinfection and Sterilization in Healthcare Facilities. Atlanta (USA): CDC; 2008. Available from: www.cdc.gov/ hicpac/Disinfection_Sterilization/acknowledg.html

5. Mahon CR, Lehman DC, Manuselis G. Textbook of diagnostic microbiology. Maryland Heights, MO: Saunders/ Elsevier; 2012.

6. Croxatto A, Prod'hom G, Greub G. Applications of MALDI-TOF mass spectrometry in clinical diagnostic microbiology. FEMS Microbiol Rev. 2011;36:380-407.

7. Wilkins R, Restrepo R, Bourne K, Daher N. Contamination level of stethoscopes used by physicians and physician assistants. J Physician Assist Educ. 2007;18:41-43.

8. The European Committee on Antimicrobial Susceptibility Testing. Breakpoint tables for interpretation of MICs and zone diameters. Version 5.0, 2015. http://www.eucast.org.

9. Magiorakos A P, Srinivasan A, Carey R B, Carmel Y, Falagas M E, Giske C G, et al. Multidrug-resistant, extensively drug-resistant and pandrug-resistant bacteria: an international expert proposal for interim standard definitions for acquired resistance. Clin Microbiol Infect. 2012;18:268281.

10. Shiferaw T, Beyene G, Kassa T, Sewunet T. Bacterial contamination, bacterial profile and antimicrobial susceptibility pattern of isolates from stethoscopes at Jimma University Specialized Hospital. Ann Clin Microbiol Antimicrob. 2013;12:39.

11. Parmar RC, Valvi CC, Sira P, Kamat JR. A prospective, randomised, double-blind study of comparative efficacy of immediate versus daily cleaning of stethoscope using 66\% ethyl alcohol. Indian J Med Sci. 2004;58:423-430.

12. Youngster I, Berkovitch M, Heyman E, Lazarovitch 
Z, Goldman M. The stethoscope as a vector of infectious diseases in the paediatric division. Acta Paediatr. 2008;97:1253-1255.

13. Zuliani-Maluf ME, Maldonado AF, Bercial ME, Pedroso SA. Stethoscope: a friend or an enemy? Sao Paulo Med J. 2002;120:13-15.

14. Sang Su K, Soo-Bong Y, Joo-Duck K, Sie Jeong R. Comparison of disinfective power according to application order of $70 \%$ isopropyl alcohol and $10 \%$ povidone-iodine. Korean J Anesthesiol. 2013;65:519-524.
15. Shobha KL, Rao PS, Thomas J. Survey of Staphylococcus isolates among hospital personnel, environment and their antibiogram with special emphasis on methicillin resistance. Indian J Med Microbiol. 2005;23:186-8.

16. Leontsini F, Papapetropoulos A, Vantarakis A. Stethoscopes as vectors of multi-resistant coagulase negative staphylococci in a tertiary hospital. Int J Med Sci Public Health. 2013;2:324-329. 